\title{
STUDI PENGARUH KONDISI KADAR AIR KAYU KELAPA TERHADAP SIFAT MEKANIS
}

\author{
Fauzan $^{1}$, Ruddy Kurniawan ${ }^{2}$, Siska Martha Sari ${ }^{3}$
}

\begin{abstract}
ABSTRAK
Kayu kelapa sebagai alternatif bahan konstruksi belum diketahui kelas dan kekuatannya secara pasti. Penggunaan kayu kelapa untuk berbagai kondisi yang dipengaruhi cuaca dan kelembaban lingkungan perlu diketahui kekuatannya untuk kadar air yang berbeda-beda dan perkiraan besar pengurangan kekuatan yang terjadi untuk perencanaan. Selain itu bisa mengetahui klasifikasi kayu kelapa berdasarkan PKKI 1961.

Benda uji yang digunakan dalam penelitian ini adalah kayu kelapa dengan umur sekitar 20 tahun dan umur 70 tahun. Penelitian ini dilakukan dengan membedakan kadar air dan berat jenis. Sifat mekanis yang dilihat adalah kuat geser sejajar serat, kuat tekan sejajar serat dan tegak lurus serat, kuat lentur sejajar serat dan kuat tarik sejajar serat. Benda uji diambil pada bagian bawah batang pohon kelapa sekitar 1-2 m. Sebelum dilakukan pengujian sifat mekanis dilakukan pengaturan kadar air benda uji.

Berdasarkan penelitian, diketahui bahwa peningkatan kadar air kayu kelapa berbanding terbalik dengan kuat tekan dan kuat tariknya, namun berbanding lurus dengan kuat gesernya. Terjadi pertambahan kekuatan yang besar pada kayu kelapa dari kadar air 20\% menuju 0\% kecuali untuk kekuatan gesernya. Berdasarkan berat jenis rata-rata yang diperoleh sebesar 0,83, maka kayu kelapa berumur 70 tahun termasuk kategori kayu kelas kuat II dan kayu kelapa berumur 20 tahun dengan berat jenis rata-rata 0,58 termasuk kategori kayu kelas kuat III. Perbedaan kekuatan kayu kelapa pada kondisi kadar air 20\% untuk umur 20 tahun dan 70 tahun terbesar terjadi pada kekuatan tekan. Faktor koreksi layan basah kayu kelapa lebih rendah dibandingkan faktor koreksi layan basah berdasarkan SNI konstruksi kayu 2002.
\end{abstract}

Kata Kunci : kayu kelapa, sifat mekanis, kadar air, berat jenis.

\section{LATAR BELAKANG}

Kayu merupakan hasil hutan dari sumber kekayaan alam, sekaligus bahan mentah yang mudah diproses untuk dijadikan barang sesuai dengan kemajuan teknologi. Kayu sampai saat ini masih banyak dicari dan dibutuhkan oleh masyarakat sebagai bahan bangunan karena kelebihan-kelebihan yang dimiliki oleh kayu. Kayu bersifat renewable, yaitu sumbernya menjamin ketersediaan sepanjang masa selama pengelolaan sumber daya alamnya dilakukan secara lestari (Surjokusumo dkk., dalam Awaludin, 2005). Kayu dapat didaur ulang secara sempurna dan $100 \%$ dapat terurai di alam sehingga menjadi satu-satunya bahan struktur yang ramah lingkungan. Material kayu memiliki berat jenis yang ringan dan proses pengerjaannya dapat dilakukan dengan peralatan yang sederhana.

Namun ketersediaan kayu terbatas dengan harga yang relatif mahal. Untuk mengatasi hal itu kayu kelapa dapat dijadikan sebagai salah satu alternatif bahan konstruksi yang bisa digunakan, tetapi

\footnotetext{
${ }^{1}$ Staf Pengajar Jurusan Teknik Sipil Fakultas Teknik Universitas Andalas, e-mail: fauzanrn@yahoo.com

${ }^{2}$ Staf Pengajar Jurusan Teknik Sipil Fakultas Teknik Universitas Andalas, e-mail: ruddykurniawan@ft.unand.ac.id

${ }^{3}$ Staf Engineer Klinik Konstruksi Pusat Studi Bencana Universitas Andalas, e-mail: siskamarthasari@yahoo.com
} 
referensi tentang kekuatan kayu kelapa belum ada di dalam PKKI 1961 dan untuk daerah Sumatera Barat belum ada penelitian tentang kekuatan mekanis kayu kelapa sehingga menyulitkan dalam perencanaan konstruksi.

Iskandar (2005) menjelaskan, setiap jenis kayu mempunyai ciri tersendiri baik sifat kimia, fisik/mekaniknya. Sebagai contoh kayu jenis fast growing spesies mempunyai sifat mekanik yang lebih lemah jika dibandingkan dengan jenis non fast growing spesies, karena kondisi sel-sel kayunya berbeda.

Kayu kelapa memiliki struktur batang yang berbeda dengan struktur kayu pada umumnya (Dwianto, 2008). Kayu kelapa sebagai tumbuhan monokotil yang tidak berkambium, kayu teras dan kayu gubal dengan letak yang berbeda dengan kayu konvensional serta tekstur yang seperti serat kayu berstruktur kasar dengan serat yang pendek dan putus-putus selain itu kayu kelapa memiliki pori-pori yang lebar.

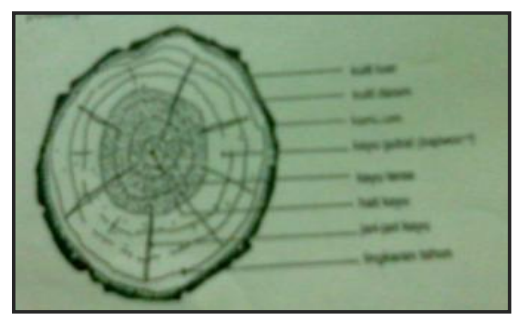

Batang dikotil

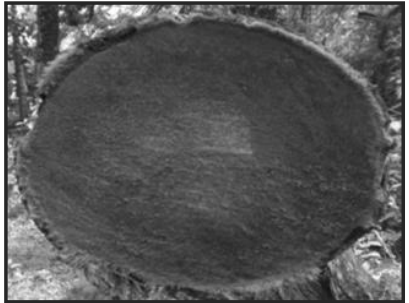

Batang monokotil

Gambar 1. Penampang Batang Kayu

Menurut Dwianto (2008), faktor-faktor alam yang mempengaruhi sifat fisik dan mekanik kayu adalah jenis kayu, umur dan tempat tumbuh, letak dalam batang, kadar air, cuaca dan jamur. Kadar air adalah salah satu faktor yang mempengaruhi sifat mekanis dari kayu karena sifat higrokopis yang dimiliki oleh kayu.

Kadar air kayu memberikan pengaruh yang sangat besar dalam pemakaian kayu. Penggunaan kayu di dalam konstruksi bisa untuk berbagai bentuk dan kondisi seperti penggunaan kayu yang dipengaruhi oleh cuaca dan kelembaban lingkungan, jadi dalam perencanaan perlu diketahui kekuatan yang dimiliki kayu kelapa dalam berbagai kondisi kadar air dan perkiraan besar pengurangan kekuatan yang terjadi. Maka dilakukan penelitian untuk mengetahui prilaku kayu kelapa terhadap pengaruh kadar air. Selain kadar air, berat jenis dari kayu juga berpengaruh terhadap sifat mekanis dari kayu. Menurut Dwianto (2008) berat jenis merupakan satu sifat kayu yang sangat penting, karena tinggi rendahnya akan mempengaruhi sifat fisik, sifat mekanis serta pemanfaatan kayu yang bersangkutan. Adapun tujuan dari penelitian ini adalah :

1. Untuk mengetahui pengaruh kadar air dan berat jenis kayu kelapa terhadap sifat mekanis kayu tersebut.

2. Untuk mengetahui perbandingan perbedaan umur terhadap kekuatan kayu kelapa tersebut.

3. Untuk mengetahui besar kekuatan kayu pada kondisi kadar air 20\% (Kondisi jenuh permukaan) dan klasifikasi kayu kelapa berdasarkan berat jenis sesuai PKKI 1961 untuk umur yang berbeda.

4. Untuk mengetahui perkiraan persentase perbedaan kekuatan kayu pada kondisi kadar air $0 \%$ dan kondisi $20 \%$.

5. Untuk mengetahui berat jenis kayu pada umur yang berbeda, dalam penelitian ini digunakan umur kayu sekitar \pm 20 tahun dan \pm 70 tahun.

6. Mengetahui faktor koreksi layan basah kayu kelapa dibandingkan dengan SNI konstruksi kayu 2002, lampiran B, pasal B.2.1, Tabel B.1.

Variabel yang digunakan dalam penelitian ini adalah jumlah kadar air dan berat jenis yang terkandung didalam kayu kelapa. Sifat mekanis kayu kelapa yang ditinjau berupa kekuatan geser 
sejajar serat, kekuatan tekan sejajar dan tegak lurus serat, kekuatan lentur dan kekuatan tarik sejajar serat.

Dari hasil penelitian ini diharapkan dapat mengetahui pengaruh kadar air dan berat jenis pada sifat mekanis kayu kelapa sehingga bisa digunakan sebagai bahan referensi untuk mengetahui kekuatan kayu kelapa dalam perencanaan kayu kelapa. Selain itu bisa bermanfaat untuk evaluasi faktor koreksi layan basah kayu kelapa dalam perencanaan struktur sesuai SNI Tata Cara Perencanaan Konstruksi Kayu 2002.

\section{SPESIMEN DAN PENGUJIAN}

\subsection{Spesimen}

Sebelum melakukan pengujian, dilakukan pengaturan kadar air dari benda uji agar diperoleh variasi kadar air. Benda uji yang digunakan pada penelitian memiliki ukuran yang berbeda-beda tergantung jenis pengujian yang dilakukan. Untuk pengujian kekuatan tarik digunakan benda uji dengan ukuran panjang $46 \mathrm{~cm}$ dan diameter $1.5 \mathrm{~cm}$, untuk pengujian berat jenis digunakan benda uji berbentuk kubus ukuran $5 \mathrm{~cm}$. Sedangkan untuk pengujian yang lain, ukuran benda uji dapat dilihat pada gambar di bawah ini :
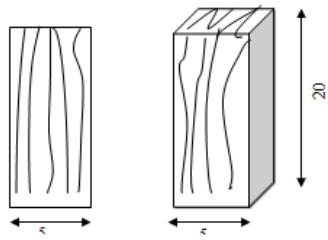

(a)

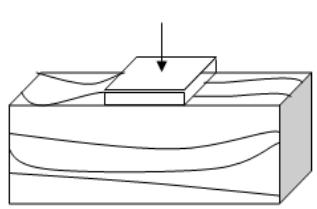

(b)

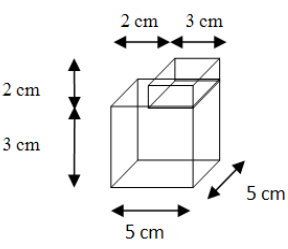

$(c)$

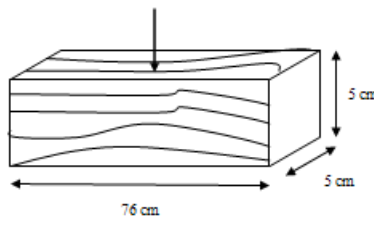

$(d)$

Gambar 2. Benda Uji Kayu, (a)

(a). Benda Uji untuk Kuat Tekan Sejajar Serat $(5 \mathrm{~cm} \times 5 \mathrm{~cm} \times 20 \mathrm{~cm}) ;(b)$. Benda Uji untuk Kuat Tekan Tegak Lurus Serat $(5 \mathrm{~cm} \times 5 \mathrm{~cm} \times 15 \mathrm{~cm})$; $(c)$. Benda Uji untuk Kuat Geser Sejajar Serat ; (d). Benda Uji untuk Kuat Lentur $(5 \mathrm{~cm} \times 5 \mathrm{~cm} \times 76 \mathrm{~cm})$

\subsection{Pengujian Sifat Mekanis Dan Penentuan Kadar Air}

Langkah-langkah yang dilakukan dalam penelitian ini adalah ;

1. Menyiapkan seluruh peralatan yang dibutuhkan meliputi, mesin penekan, timbangan digital, mistar dan alat penjepit (untuk pengujian kuat geser).

2. Memotong kayu sesuai dengan dimensi benda uji.

3. Melakukan penimbangan awal pada benda uji sebagai berat A dan luas benda uji.

4. Melakukan penekanan pada benda uji, untuk pengujian kekuatan, sedangkan untuk pengujian berat jenis tidak dilakukan penekanan.

5. Setelah benda uji pecah untuk pengujian kuat geser dan benda uji tidak mampu menahan beban lagi untuk pengujian kuat tekan, mesin penekan dimatikan.

6. Mencatat hasil penekanan yang diperoleh

7. Menghitung nilai kuat tekan dan kuat geser menggunakan rumus berikut :

- Kuat geser $(\tau)$, dengan rumusan :

$$
\tau=\frac{P}{A}\left(\mathrm{~kg} / \mathrm{cm}^{2}\right)
$$

- Kuat tekan $\left(\sigma_{t k}\right)$, dengan rumusan :

$$
\sigma_{t k}=\frac{P}{A}\left(\mathrm{~kg} / \mathrm{cm}^{2}\right)
$$


- Kuat tarik sejajar serat $\left(f_{/ /}\right)$, dengan rumusan :

$$
f_{/ /}=\frac{P}{A}(\mathrm{MPa})
$$

- Kuat lentur $\left(\sigma_{l t}\right)$, dengan rumusan :

$$
\sigma_{t k}=\frac{M}{W}=\frac{M y}{I_{x}}=\frac{3 P L}{2 B H^{2}}\left(\mathrm{~kg} / \mathrm{cm}^{2}\right)
$$

dimana :

$$
\begin{aligned}
P & =\text { Pembebanan maksimum } \\
A & =\text { Luas bidang yang tertekan }\left(\mathrm{cm}^{2}\right) \\
L & =\text { Panjang benda uji }(\mathrm{cm}) \\
B & =\text { Lebar benda uji }(\mathrm{cm}) \\
H & =\text { Tinggi benda uji }(\mathrm{cm})
\end{aligned}
$$

8. Melakukan pengovenan pada benda uji selama 24 jam setelah itu melakukan penimbangan akhir (B).

9. Menghitung kadar air benda uji, dengan rumusan :

$$
\text { Kadar Air Kayu }=\frac{A-B}{B} \times 100 \%
$$

10. Melakukan perhitungan berat jenis kayu, dengan rumusan :

$$
\text { Berat Jenis Kayu }=\frac{B}{\text { Volume }}
$$

\section{HASIL DAN ANALISA}

Berdasarkan penelitian yang telah dilakukan, secara visual kayu kelapa berwarna merah muda untuk umur 20 tahun dan merah tua kehitaman untuk umur 70 tahun. Kayu ini berstruktur kasar dengan serat yang pendek. Serat kayu berwarna lebih gelap dibanding bagian kayu yang lain, sehingga kayu kelapa memiliki nilai estetika yang unik dibanding kayu yang lain.

Setelah dilakukan penelitian dan pengolahan data menggunakan rumus yang telah diuraikan di atas maka diperoleh grafik hubungan antara kadar air, berat jenis dan umur dengan sifat mekanis kayu kelapa.

\subsection{Kadar Air terhadap Kekuatan}

Kollmann dan Cote (1968) dalam Iskandar (2005) menyatakan bahwa, biasanya kayu akan bertambah kuat apabila terjadi penurunan kadar air, terutama bila terjadi di bawah titik jenuh seratnya. Hal senada juga disampaikan oleh Wood Handbook (USFPL, 1994) dalam Iskandar (2005), hubungan antara kadar air dan kekuatan kayu pada umumnya dijelaskan pada Gambar 3, dimana kadar air berbanding terbalik dengan kekuatan kayu.

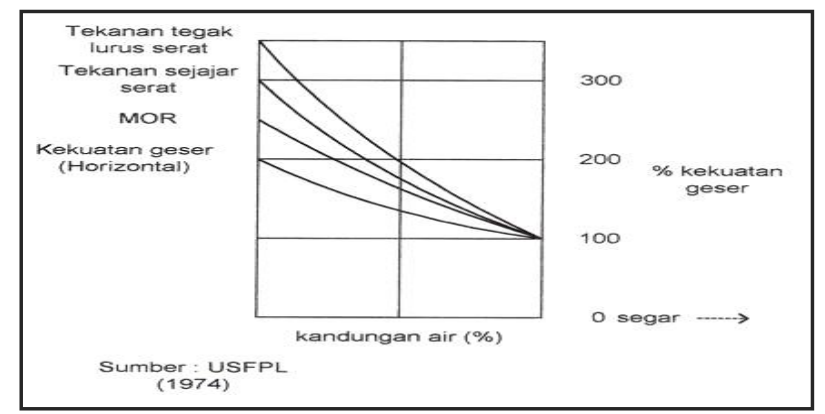

Gambar 3. Grafik Hubungan Kadar Air terhadap Kekuatan Kayu Secara Umum 
Tidak jauh berbeda pendapat Widiawati (1999) dalam Dwianto (2008) tentang penelitian terhadap kayu kelapa dengan membandingkan bagian atas, tengah dan bawah pada berat jenis yang berbeda, dimana peningkatan kadar air kayu kelapa berbanding terbalik dengan kekuatannya (kuat geser, kuat tekan dan kuat tarik), namun untuk berat jenis kayu yang berbeda (Tabel 1).

Tabel 1. Nilai Propertis Kayu Kelapa dari Bagian Pangkal, Tengah dan Ujung Batang

\begin{tabular}{|r|c|c|c|c|c|}
\hline $\begin{array}{c}\text { Part of } \\
\text { Stem }\end{array}$ & $\begin{array}{c}\text { Specific } \\
\text { gravity }\end{array}$ & $\begin{array}{c}\text { Moisture } \\
\text { content } \\
(\%\end{array}$ & $\begin{array}{c}\text { Shear strength } \\
\left(\mathrm{kg} / \mathrm{cm}^{2}\right)\end{array}$ & $\begin{array}{c}\text { Compressin } \\
\text { strength } \\
\left(\mathrm{kg}^{2} \mathrm{~cm}^{2}\right)\end{array}$ & $\begin{array}{c}\mathrm{M} \\
0 \\
\mathrm{R}\end{array}$ \\
\hline Upper & 0.6 & 81.7 & 41.1 & 188.81 & 233 \\
\hline Middle & 0.7 & 68.0 & 45.9 & 315.00 & 749 \\
\hline Bottom & 0.8 & 46.3 & 89.6 & 453.97 & 838 \\
\hline
\end{tabular}

Sumber: Widiastuti (1999) dalam Dwianto (2008)

\subsubsection{Kadar Air Terhadap Kekuatan Geser}

Berdasarkan hasil penelitian yang telah dilakukan, didapatkan hubungan k0adar air dengan kuat geser kayu kelapa, seperti dibawah ini :

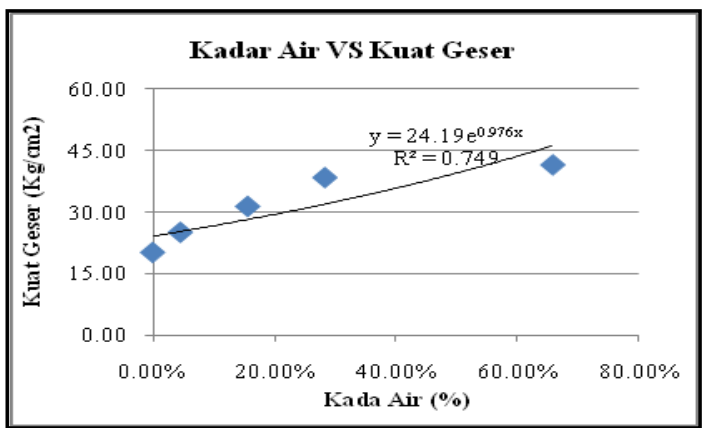

(a). Umur 20 tahun

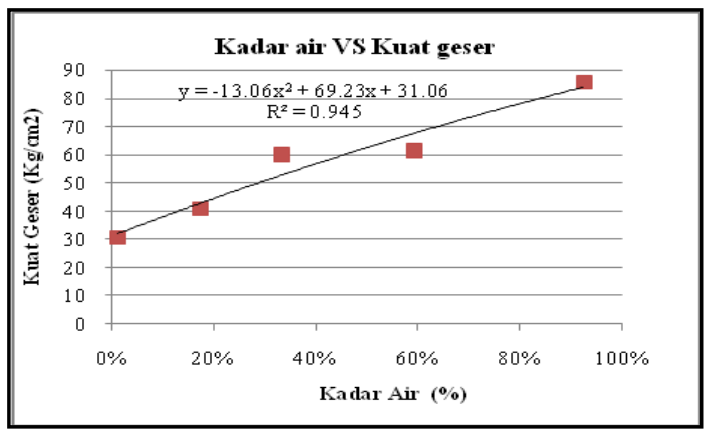

(b). Umur 70 tahun

Gambar 4. Grafik Hubungan Kadar Air vs Kuat Geser Kayu Kelapa

Gambar 4 menunjukkan hubungan antara kadar air terhadap kuat geser sejajar serat pada umur 20 tahun dan 70 tahun. Untuk umur 20 tahun setelah dilakukan regresi dengan mengambil nilai korelasi $\left(R^{2}\right)$ terbesar dari beberapa trendline yang ada untuk memperoleh nilai regresi paling akurat, sehingga diperoleh grafik dengan nilai korelasi sebesar 0.749 antara kadar air dengan kuat geser, dimana pertambahan kadar air menyebabkan penambahan kekuatan geser pada kayu secara eksponensial. Sedangkan untuk kayu kelapa umur 70 tahun, hubungan antara kadar air dan kuat geser sejajar serat, dengan nilai korelasi $\left(R^{2}\right)$ terbesar dari beberapa trendline sebesar 0.945 , dimana pertambahan kadar air menyebabkan penambahan kekuatan geser pada kayu secara kuadratik.

Namun hasil yang diperoleh ini berbeda dengan kondisi kayu pada umumnya ataupun penelitian tentang kayu kelapa seperti terlihat pada Tabel 1, dimana penambahan kadar air pada kayu menyebabkan pengurangan kekuatan gesernya. Perbedaan ini terjadi karena penelitian tersebut membandingkan pengaruh pengambilan benda uji pada satu batang terhadap kekuatan, sehingga berat jenis yang diperoleh berbeda-beda. Sedangkan penelitian ini memfokuskan pada benda uji dengan berat jenis yang relatif sama hanya kadar air yang dibedakan.

Selain itu penyebab perbedaan hasil penelitian yang diperoleh dengan kondisi kayu pada umumnya adalah struktur kayu kelapa yang terdiri dari serat-serat yang dilapisi oleh zat seperti gabus, dimana saat pertambahan kadar air, zat ini ikut mengembang sehingga meningkatkan kekuatan geser kayu kelapa. 


\subsubsection{Kadar Air Terhadap Kekuatan Tekan Sejajar Serat}

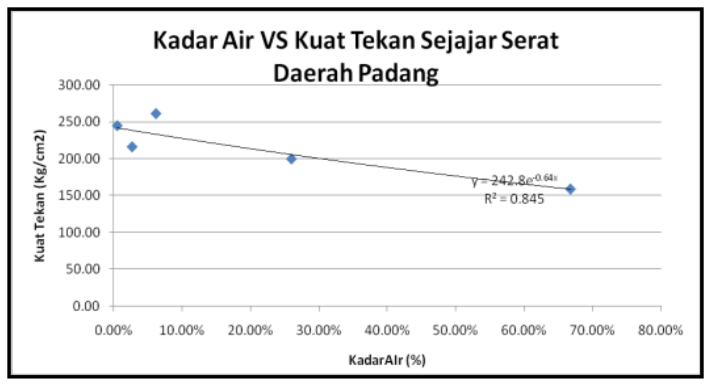

(a). Umur 20 tahun

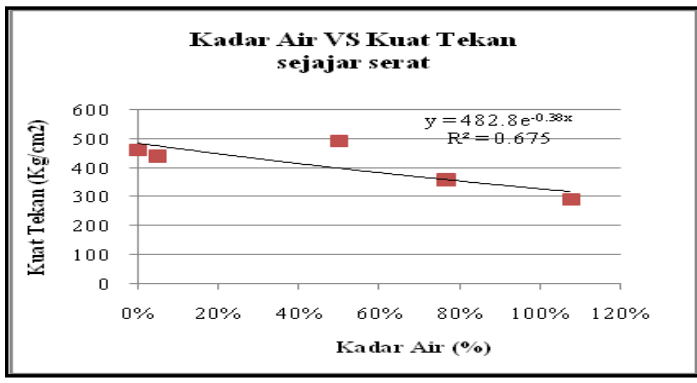

(b). Umur 70 tahun

Gambar 5. Grafik Hubungan Kadar Air vs Kuat Tekan Sejajar Serat Kayu Kelapa

Hubungan kadar air dan kekuatan tekan sejajar serat dapat dilihat pada Gambar 5. Penambahan kadar air menyebabkan penurunan kekuatan tekan sejajar serat secara eksponensial. Berdasarkan regresi yang telah dilakukan, diperoleh nilai korelasi $\left(R^{2}\right)$ sebesar 0.845 untuk umur 20 tahun dan 0.675 untuk umur 70 tahun.

\subsubsection{Kadar Air Terhadap Kekuatan Tekan Tegak Lurus Serat}

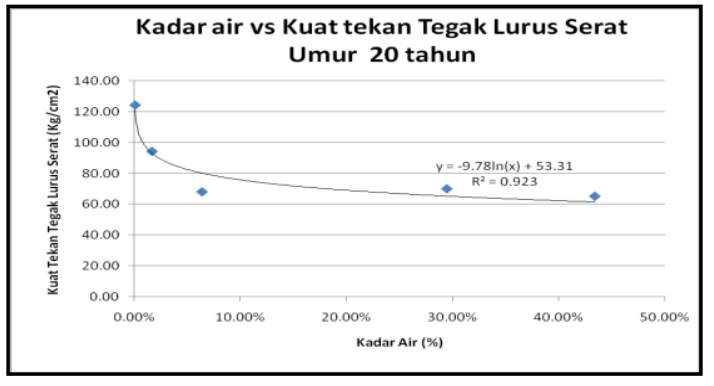

(a). Umur 20 tahun

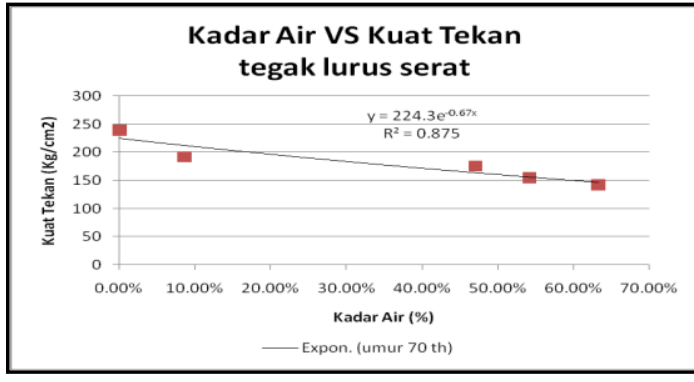

(b). Umur 70 tahun

\section{Gambar 6. Grafik Hubungan Kadar Air vs Kuat Tekan Tegak Lurus Serat Kayu Kelapa}

Berdasarkan Gambar 6 terlihat hubungan antara kadar air dan kekuatan tekan tegak lurus serat kayu kelapa. Trendline yang telah dilakukan menghasilkan nilai korelasi sebesar 0.923 untuk umur 20 tahun dalam bentuk grafik kuadrat dan 0.875 untuk umur 70 tahun dalam bentuk grafik eksponensial. Jika diamati sebaran titik yang terjadi pada gambar 6 terlihat bahwa perbedaaan kekuatan tekan tegak lurus serat tidak terlalu besar setelah kadar air lebih besar dari $20 \%$, sedangkan perbedaan kekuatan dari kadar air 0\% - 20\% cukup besar.

\subsubsection{Kadar Air Terhadap Kekuatan Lentur}

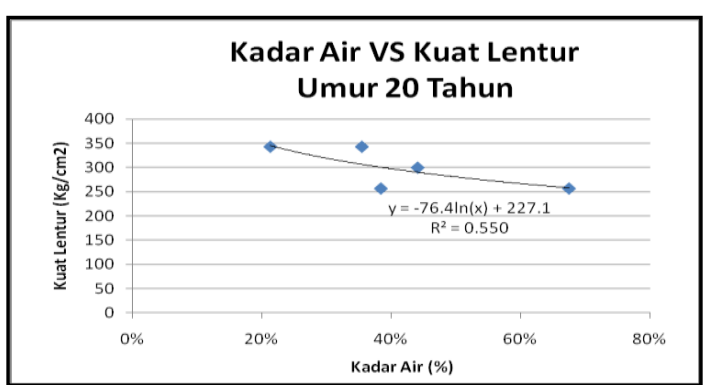

(a). Umur 20 tahun

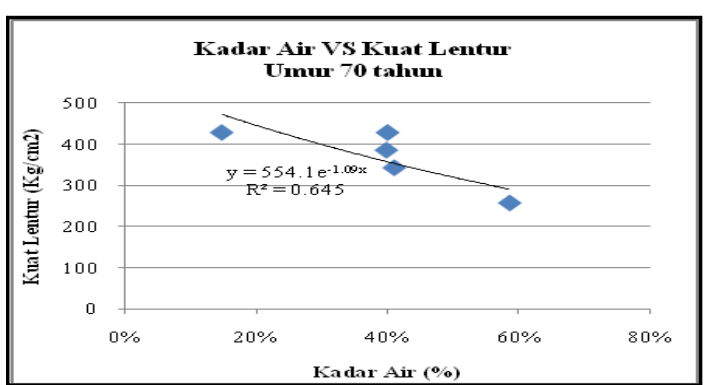

(b). Umur 70 tahun

Gambar 7. Grafik Hubungan Kadar Air vs Kuat Lentur Kayu Kelapa 
Berdasarkan beberapa trendline yang telah dilakukan maka diperoleh hubungan antara kadar air terhadap kekuatan lentur kayu kelapa seperti terlihat pada Gambar 7. Untuk umur 20 tahun berupa grafik logaritma dengan nilai korelasi $\left(R^{2}\right) 0.55$ dan untuk umur 70 tahun dengan hubungan eksponensial . Dari grafik terlihat pertambahan kadar air menyebabkan pengurangan kekuatan lentur kayu.

\subsubsection{Kadar Air Terhadap Kekuatan Tarik Sejajar Serat}

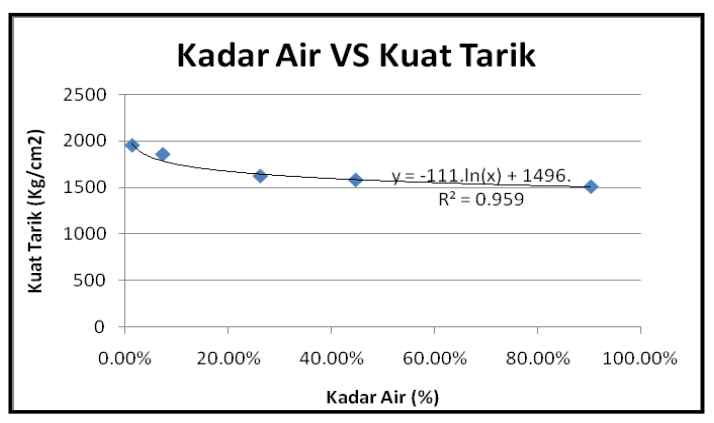

(a). Umur 20 tahun

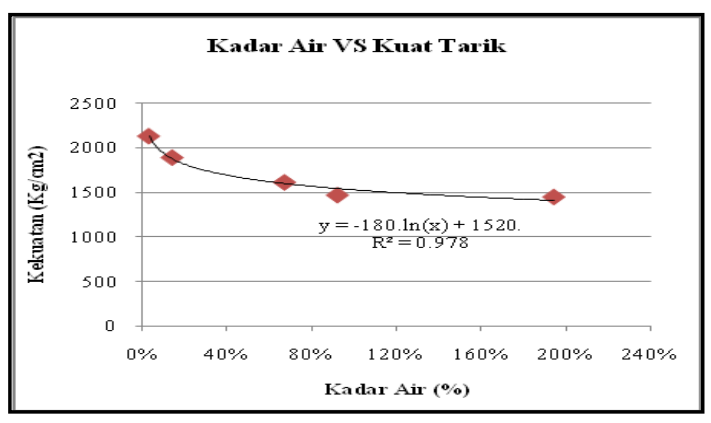

(b). Umur 70 tahun

Gambar 8. Grafik Hubungan Kadar Air vs Kuat Tarik Sejajar Serat Kayu Kelapa

Grafik di atas menggambarkan hubungan antara kadar air terhadap kuat tekan tegak lurus serat pada umur 20 dan 70 tahun. Setelah dilakukan regresi dengan mengambil nilai korelasi terbesar dari beberapa trendline yang ada untuk memperoleh nilai regresi paling akurat, sehingga diperoleh grafik dengan nilai korelasi sebesar 0.959 untuk umur 20 tahun dalam bentuk grafik kuadrat dan 0.978 untuk umur 70 tahun dalam bentuk grafik logaritma, dimana pertambahan kadar air menyebabkan pengurangan kekuatan tarik sejajar serat.

Pada hubungan antara kadar air dan kuat tarik sejajar serat ini lebih jelas terlihat, perbedaaan kekuatan tidak terlalu besar setelah kadar air 20\%, sedangkan perbedaan kekuatan tarik sejajar serat cukup besar terjadi pada kadar air 0\% - 20\%. Jika dilihat dari semua grafik yang ada ternyata hubungan kadar air terhadap kekuatan kayu kelapa adalah berbanding terbalik, kecuali untuk kuat geser. Hal ini tidak jauh berbeda dengan kayu konvensional lainnya.

Penambahan kadar air dari kering tanur $(0 \%)$ menuju kondisi kering udara $( \pm 15 \%-20 \%)$ terjadi penurunan kekuatan yang cukup besar pada kekuatan kayu kelapa kecuali pada kuat gesernya, sedangkan setelah kondisi kering udara (SSD) terlewati pengurangan kekuatan berjalan cukup lambat. Berdasarkan rumus regresi yang telah diperoleh, maka perubahan kekuatan tersebut dapat dilihat pada tabel dibawah ini.

Tabel 2. Perubahan Kekuatan Kayu Kelapa Terhadap Kadar Air yang Terkandung

\begin{tabular}{|c|c|c|c|c|c|c|c|c|c|c|}
\hline \multirow{2}{*}{$\begin{array}{c}\text { Kadar } \\
\text { Air }\end{array}$} & \multirow{2}{*}{$\begin{array}{c}\text { Perbedaan Kuat } \\
\text { Geser }\left(\mathbf{k g} / \mathbf{c m}^{2}\right)\end{array}$} & \multicolumn{4}{|c|}{$\begin{array}{c}\text { Perbedaan Kuat Tekan } \\
\text { Tegak Lurus } \\
\text { Serat }\left(\mathbf{k g} / \mathbf{c m}^{2}\right)\end{array}$} & \multicolumn{2}{c|}{$\begin{array}{c}\text { Sejajar Serat } \\
\left(\mathbf{k g} / \mathbf{c m}^{2}\right)\end{array}$} & \multicolumn{2}{c|}{$\begin{array}{l}\text { Perbedaan Kuat } \\
\text { Lentur }\left(\mathbf{k g} / \mathbf{c m}^{2}\right)\end{array}$} & \multicolumn{2}{|c|}{$\begin{array}{l}\text { Pebedaan Kuat } \\
\text { Tarik }\left(\mathbf{K g} / \mathbf{c m}^{2}\right)\end{array}$} \\
\hline$(\%)$ & 20 th & 70 th & 20 th & 70 th & 20 th & 70 th & 20 th & 70 th & 20 th & 70 th \\
\hline 0 & 0 & 0 & 0 & 0 & 0 & 0 & 0 & 0 & 0 & 0 \\
\hline 20 & 5 & 13 & 54 & 28 & 29 & 35 & 422 & 109 & 613 & 994 \\
\hline 40 & 6 & 12 & 7 & 25 & 26 & 33 & 53 & 87 & 77 & 125 \\
\hline 60 & 8 & 11 & 4 & 22 & 23 & 30 & 31 & 70 & 45 & 73 \\
\hline 80 & 9 & 10 & 3 & 19 & 20 & 28 & 22 & 56 & 32 & 52 \\
\hline 100 & 11 & 9 & 2 & 16 & 17 & 26 & 17 & 45 & 25 & 40 \\
\hline
\end{tabular}


Perbedaan kekuatan yang cukup besar tersebut disebabkan karena saat air masuk kedalam dinding sel,ikatan antara molekul-molekul pada kayu menjadi lemah dan sifat elastisnya berkurang sehingga mempengaruhi kekutan pada kayu tersebut. Hal senada juga disampaikan Kollmann dan Cote (1968) yang menyatakan bahwa biasanya kayu akan bertambah kuat apabila terjadi penurunan kadar air, terutama bila terjadi di bawah titik jenuh serat.

Maka jika dipersentasekan besarnya nilai pengurangan kekuatan kayu akibat penambahan kadar air dari kondisi $0 \%$ sampai kondisi jenuh serat (20\%) adalah seperti tabel di bawah ini :

Tabel 3. Persentase Perbedaan Kekuatan Kayu Kelapa pada Kondisi 0\% dan 20\%

\begin{tabular}{|c|c|c|c|c|c|}
\hline \multirow{2}{*}{ Umur } & \multicolumn{2}{|c|}{ KuatTekan } & \multirow{2}{*}{ Kuat Tarik } & \multirow{2}{*}{ Kuat Geser } & \multirow{2}{*}{ Kuat Lentur } \\
\cline { 2 - 3 } & Tegak Lurus Serat & Sejajar Serat & & & \\
\hline 20 th & $42.87 \%$ & $13.06 \%$ & $12.28 \%$ & $25.09 \%$ & $16.81 \%$ \\
\hline 70 th & $12.19 \%$ & $1.51 \%$ & $8.32 \%$ & $42.87 \%$ & $39.27 \%$ \\
\hline
\end{tabular}

Dari tabel diatas dapat diketahui bahwa penambahan umur kayu akan memperkecil pengurangan kekuatan tarik dan tekan kayu jika terjadi penambahan kadar air karena kayu yang umurnya tua relatif stabil karena kayu tersebut telah keras. Namun untuk kuat geser dan lentur kayu makin tua kayu perbedaan kekuatannya semakin besar.

\subsection{Berat Jenis Terhadap Kekuatan}

Penelitian tentang berat jenis kayu kelapa telah dilakukan oleh beberapa peneliti seperti yang dilakukan oleh Sektianto (2001), memperoleh berat jenis rata-rata kayu kelapa sebesar 0.54, sedang menurut Isyuanto (2002) dari hasil penelitiannya diperoleh berat jenis rata-rata kayu kelapa 0.72 dan Ginting (2007) memperoleh berat jenis rata-rata kayu kelapa sebesar 0.74. Namun penelitian tersebut tidak mencantumkan cara pengambilan sampel, sehingga terjadi perbedaan berat jenis yang cukup signifikan.

Brown et al. (1952) menyatakan bahwa berat jenis kayu bervariasi diantara berbagai jenis pohon dan diantara pohon dari satu jenis yang sama. Variasi ini juga terjadi pada posisi yang berbeda dari satu pohon. Adanya variasi berat jenis kayu tersebut disebabkan oleh perbedaan dalam jumlah zat penyusun dinding sel dan kandungan zat ekstraktif per unit volume.

Berat jenis kayu kelapa yang telah diteliti dalam satu batang memiliki nilai yang berbeda-beda, namun jika dirata-ratakan berat jenis kayu kelapa untuk umur 20 tahun adalah $0.58 \mathrm{~g} / \mathrm{cm}^{3}$ dan 0.83 $\mathrm{g} / \mathrm{cm}^{3}$ untuk umur 70 tahun. Jadi jika dilihat berdasarkan berat jenisnya maka kayu kelapa digolongkan dalam kelas II untuk kayu kelapa umur 70 tahun dan kelas III untuk umur 20 tahun sesuai dengan tabel di bawah ini tentang pengelompokan kayu berdasarkan PKKI 1961.

Tabel 4. Klasifikasi Kayu Berdasarkan Berat Jenis

\begin{tabular}{|c|c|c|c|}
\hline $\begin{array}{c}\text { Kelas kuat } \\
\text { kayu }\end{array}$ & Berat jenis & $\begin{array}{c}\text { Kuat lentur mutlak } \\
\mathrm{kg} / \mathrm{cm}^{2}\end{array}$ & $\begin{array}{c}\text { kuat tekan mutlak } \\
\mathrm{kg} / \mathrm{cm}^{2}\end{array}$ \\
\hline I & $>0,90$ & $>1100$ & $>650$ \\
\hline II & $0,90-0,60$ & $1100-725$ & $650-425$ \\
\hline III & $0,60-0,40$ & $725-500$ & $425-300$ \\
\hline IV & $0,40-0,30$ & $500-360$ & $300-215$ \\
\hline V & $<0,30$ & $<360$ & $<215$ \\
\hline
\end{tabular}

(Sumber : PKKI 196)

Untuk menentukan kekuatan kayu biasanya kadar air maksimum yang diperbolehkan $20 \%$ dalam suatu pengukuran kekuatan bahan. Maka untuk mengetahui kekuatan kayu, digunakan kadar air 
$20 \%$ dan ditentukan dari rumus regresi yang telah diperoleh dari grafik sebelumnya. Hasil perhitungan kekuatan kayu kelapa tersebut terlihat pada Tabel 5 :

Tabel 5. Hasil Perhitungan Kekuatan Kayu pada Kadar Air $20 \%$

\begin{tabular}{|c|c|c|c|c|c|}
\hline \multirow{2}{*}{ Umur } & \multicolumn{2}{|c|}{ KuatTekan $\left(\mathrm{kg} / \mathrm{cm}^{2}\right)$} & \multirow{2}{*}{$\begin{array}{c}\text { Kuat Tarik } \\
\left(\mathrm{kg} / \mathrm{cm}^{2}\right)\end{array}$} & \multirow{2}{*}{$\begin{array}{c}\text { Kuat Geser } \\
\left(\mathrm{kg} / \mathrm{cm}^{2}\right)\end{array}$} & \multirow{2}{*}{$\begin{array}{c}\text { Kuat Lentur } \\
\left(\mathrm{kg} / \mathrm{cm}^{2}\right)\end{array}$} \\
\hline & Tegak Lurus Serat & Sejajar Serat & & & \\
\hline 20 th & 60.67 & 204.73 & 1717.57 & 30.11 & 348.972 \\
\hline 70 th & 194.06 & 471.77 & 1916.19 & 44.35 & 403.06 \\
\hline
\end{tabular}

Jika dibandingkan antara kayu kelas II dan kelas III pada Tabel 4 dengan nilai kekuatan mekanik yang dimiliki oleh kayu kelapa pada Tabel 5, terlihat bahwa untuk kekuatan tekan kayu kelapa masih masuk dalam bentang kelas kuat II untuk kekuatan tekan, namun untuk kekuatan lentur berdasarkan PKKI 1961, kayu kelapa memiliki nilai kuat lentur yang lebih kecil, berarti kayu kelapa memiliki nilai kuat lentur rendah dibanding dengan kayu pada umumnya. Kuat lentur sangat erat hubungannya dengan serat yang dimiliki oleh kayu. Berdasarkan hal tersebut, kecilnya kuat lentur kayu kelapa disebabkan karena serat yang dimilikinya putus-putus dan tidak menyatu seperti serat kayu konvensional yang tidak terputus dari pangkal sampai ke ujung.

Berdasarkan hasil di atas maka kayu kelapa kurang cocok digunakan untuk konstruksi yang menahan lentur, jadi kayu kelapabaik untuk konstruksi kuda-kuda.

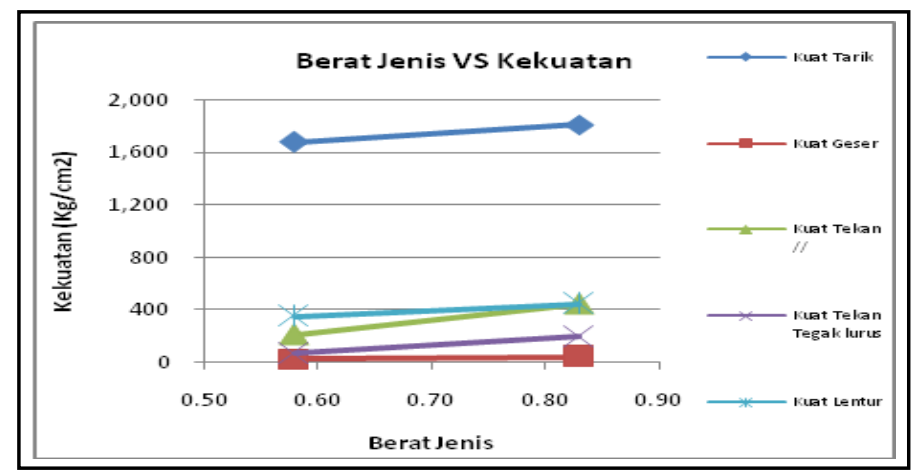

Gambar 9. Grafik Hubungan Berat Jenis terhadap Kuat Geser Sejajar Serat Kayu

Berdasarkan grafik di atas dapat dilihat bahwa peningkatan berat jenis seiring dengan peningkatan kekuatan kayu. Hubungan berat jenis dengan kekuatan ini linier karena dipengaruhi oleh berat kering oven dari kayu sehingga tidak dipengaruhi kadar air yang berubah secara nonlinier. Hal ini sesuai dengan PKKI 1961 yang menjelaskan bahwa sifat mekanis kayu sebanding dengan berat jenisnya. Kekuatan tarik kayu kelapa sangat besar dibandingkan dengan kekuatan mekaniknya lain, terlihat pada grafik kuat tarik berada jauh diatas. Namun untuk perbandingan kekuatan antara berat jenis yang berbeda, kuat tekan sejajar serat memiliki nilai yang cukup besar, terlihat dari kecuraman grafik. Jadi dalam penggunaan kayu kelapa untuk struktural yang menahan tekan (seperti kolom), berat jenis kayu sangat menentukan. Untuk kuat geser dan kuat lentur grafiknya relatif landai dengan perbedaan kekuatan kecil. Jadi semakin besar berat jenis kayu kelapa semakin besar nilai kuat tekannya tetapi pertambahan kekuatan tarik, geser dan lentur tidak terlalu besar.

Gaya dukung kayu terhadap lenturan akan lebih besar dibandingkan terhadap desakan (tekanan) tetapi lebih kecil daripada terhadap tarikan. Pada gambar terlihat bahwa kuat lentur lebih besar dari kuat tekan, namun kekuatan terbesar adalah kuat tarik. Jika dibandingkan kekuatan tekan tegak lurus serat dengan sejajar serat, maka kekuatan terbesar adalah kekuatan sejajar serat, sebagaimana dijelaskan Dumanauw (1984), Kekuatan tekan tegak lurus arah serat pada semua kayu lebih kecil dibandingkan keteguhan sejajar arah serat. 


\section{KADAR AIR TERHADAP KEKUATAN PADA UMUR YANG BERBEDA}

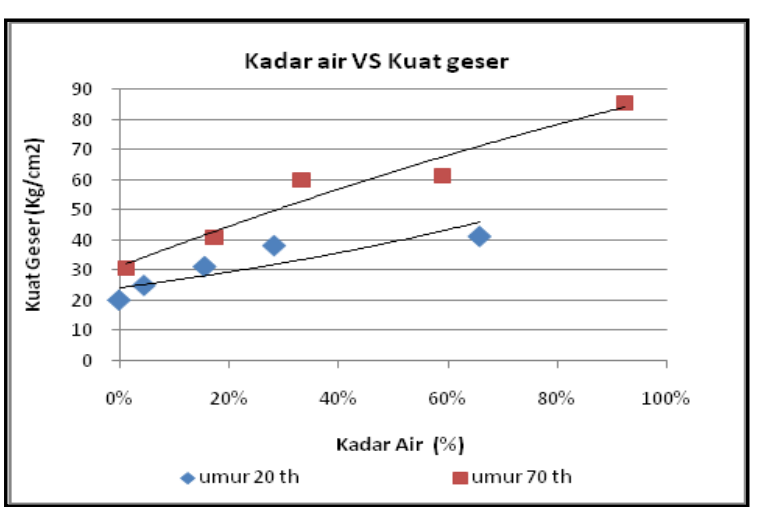

Gambar 10. Grafik Hubungan Kadar Air terhadap Kuat Geser

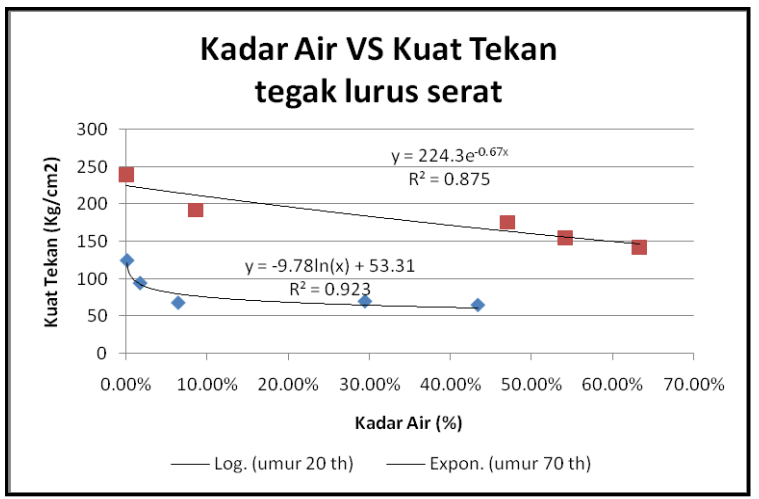

Gambar 12. Grafik Hubungan Kadar Air vs Kuat Tegak Lurus Serat Kayu

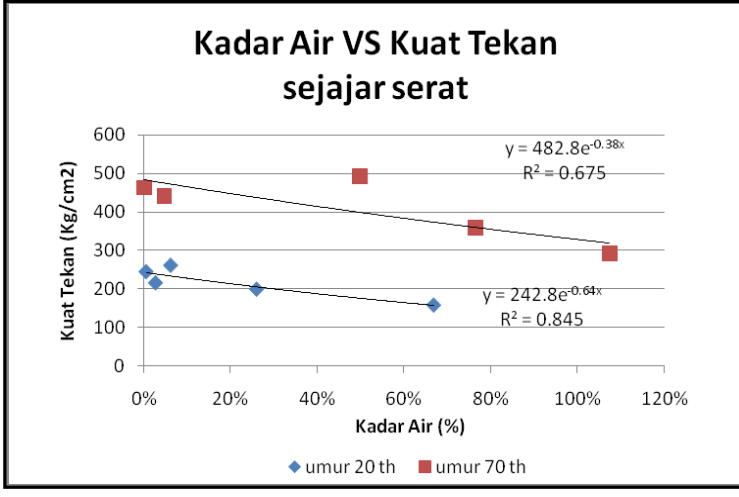

Gambar 11. Grafik Hubungan Kadar Air vs Kuat Tekan Sejajar Serat Kayu

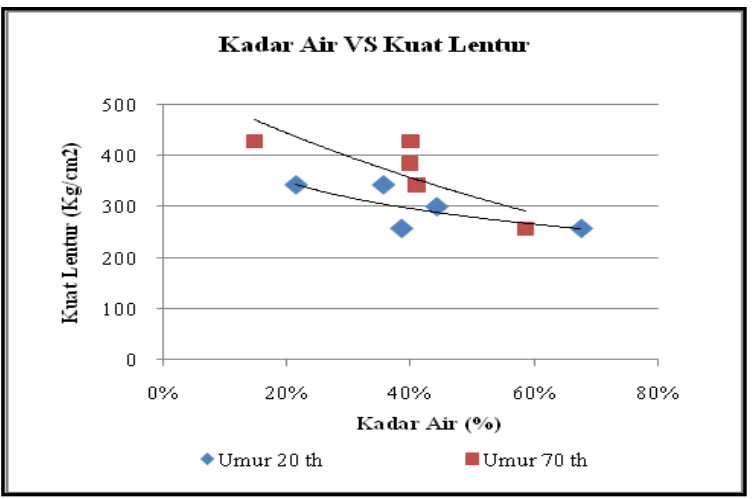

Gambar 13. Grafik Hubungan Kadar Air terhadap Kuat Lentur Kayu

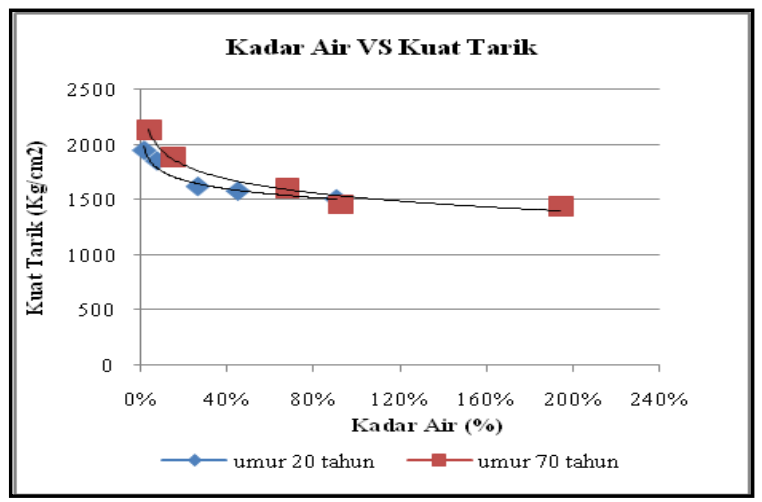

Gambar 13. Grafik Hubungan Kadar Air terhadap Kuat Tarik Sejajar Serat Kayu

Grafik diatas menunjukkan hubungan antara umur kayu pohon kelapa terhadap kekuatan yang dimilikinya. Perbedaan kekuatan tekan baik sejajar serat ataupun tegak lurus serat cukup besar jika dibandingkan dengan perbedaan kekuatan pada kuat geser sedangkan pada kuat tarik perbedaannya sangat kecil. Hal ini sesuai dengan penjelasan Timoshenko (1961), bahwa kadar air kayu besar pengaruhnya terhadap kekuatan kayu, terutama daya dukungnya terhadap kekuatan tekan sejajar arah serat dan tegak lurus arah serat. Jika dipersentasekan besarnya nilai kekuatan kayu kelapa umur 20 tahun terhadap umur 70 tahun dapat dilihat pada tabel di bawah ini : 
Tabel 6. Persentase Perbandingan Kekuatan Kayu Kelapa Umur 20 Tahun dan 70 Tahun

\begin{tabular}{|c|c|c|c|c|c|c|}
\hline \multirow{2}{*}{ Umur } & \multirow{2}{*}{$\begin{array}{c}\text { Berat Jenis } \\
\left(\mathrm{kg} / \mathrm{cm}^{3}\right)\end{array}$} & \multirow{2}{*}{$\begin{array}{c}\text { Kuat Geser } \\
\left(\mathrm{kg} / \mathrm{cm}^{2}\right)\end{array}$} & \multicolumn{2}{|c|}{ Kuat Tekan $\left(\mathrm{kg} / \mathrm{cm}^{2}\right)$} & \multirow{2}{*}{$\begin{array}{c}\text { Kuat Lentur } \\
\left(\mathbf{k g} / \mathbf{c m}^{2}\right)\end{array}$} & \multirow{2}{*}{$\begin{array}{c}\text { Kuat Tarik } \\
\left(\mathbf{k g} / \mathbf{c m}^{2}\right)\end{array}$} \\
\hline & & & \begin{tabular}{|l} 
Tegak Lurus Serat \\
\end{tabular} & Sejajar Serat & & \\
\hline 20 th & 0.58 & 30.11 & 60.67 & 204.73 & 348.97 & $1,717.57$ \\
\hline 70 th & 0.83 & 44.35 & 194.06 & 471.77 & 403.06 & $1,916.19$ \\
\hline Selisih (\%) & $23.82 \%$ & $32.11 \%$ & $68.74 \%$ & $56.60 \%$ & $13.42 \%$ & $10.37 \%$ \\
\hline
\end{tabular}

Jadi peningkatan kekuatan yang akan terjadi dari kayu berumur 20 tahun ke 70 tahun diperkirakan $68,74 \%$ untuk kuat tekan tegak lurus serat, $56.6 \%$ untuk kuat tekan sejajar serat, sejajar serat, $32.11 \%$ untuk kuat geser dan $13.42 \%$ untuk kuat lentur, $10.37 \%$ untuk kuat tarik. Dapat diketahui bahwa kuat tekan kayu kelapa sangat dipengaruhi oleh umur kayu, terjadi perbedaan kekuatan yang cukup besar antara umur kayu 20 tahun dan 70 tahun. Hal berbeda terlihat pada kuat tarik dan kuat lentur dimana perbedaan umur tidak begitu besar mempengaruhi kekuatan kayu tersebut. Jadi dalam perencanaan, jika menggunakan kayu untuk struktur dengan beban tekan dominan sebaiknya menggunakan kayu kelapa umur tua agar kekuatan yang diperoleh maksimal, sedangkan jika beban yang dominan adalah tarik atau geser umur tidak begitu dipermasalahkan.

\section{KONDISI LAYAN BASAH KAYU KELAPA}

Kadar air kayu memberikan pengaruh yang sangat besar dalam pemakaian kayu. Penggunaan kayu didalam konstruksi bisa untuk berbagai bentuk dan kondisi seperti penggunaan kayu yang dipengaruhi oleh cuaca dan kelembaban lingkungan, jadi dalam perencanaan perlu diketahui kekuatan yang dimiliki kayu kelapa dalam berbagai kondisi kadar air terutama pada kondisi basah.

Faktor layan basah menurut SNI Tata Cara Perencanaan Konstruksi Kayu (2002) adalah nilai yang digunakan untuk memperhitungkan kadar air masa layan yang lebih tinggi dari 19\% untuk kayu masif dan $16 \%$ untuk produk kayu yang dilem. Nilai kadar air 19\% adalah nilai kadar air kering permukaan untuk semua jenis kayu, maka untuk kayu kelapa nilai kadar air kering permukaan yang digunakan sesuai perhitungan adalah 19\%. Sedangkan nilai kadar air pada masa layan basah diasumsikan $100 \%$. Penentuan nilai kekuatannya dilakukan menggunakan rumus regresi grafik yang telah didapatkan sebelumnya. Maka diperoleh hasil perhitungan sebagai berikut :

Tabel 7. Faktor Koreksi Layan Basah Kayu Kelapa

\begin{tabular}{|c|c|c|c|c|c|c|}
\hline \multirow{2}{*}{ Umur } & \multirow{2}{*}{$\begin{array}{c}\text { Kadar Air } \\
(\%)\end{array}$} & \multirow{2}{*}{$\begin{array}{c}\text { Kuat Geser } \\
\left(\mathbf{k g} / \mathbf{c m}^{2}\right)\end{array}$} & \multicolumn{2}{|c|}{ Kuat Tekan $\left(\mathrm{kg} / \mathrm{cm}^{2}\right)$} & \multirow{2}{*}{$\begin{array}{c}\text { Kuat Lentur } \\
\left(\mathbf{k g} / \mathbf{c m}^{2}\right)\end{array}$} & \multirow{2}{*}{$\begin{array}{c}\text { Kuat Tarik } \\
\left(\mathbf{k g} / \mathbf{c m}^{2}\right)\end{array}$} \\
\hline & & & Tegak Lurus Serat & Sejajar Serat & & \\
\hline 20 th & $100,00 \%$ & 64,20 & 53,31 & 128,03 & 227,10 & 1496,00 \\
\hline 70 th & $19,00 \%$ & 29,12 & 69,55 & 215,00 & 353,98 & $1.680,34$ \\
\hline \multicolumn{2}{|c|}{ Perbandingan } & 2,20 & 0,77 & 0,60 & 0,64 & 0,89 \\
\hline 20 th & $100,00 \%$ & 87,23 & 114,78 & 330,17 & 186,30 & 1520,00 \\
\hline 70 th & $19,00 \%$ & 43,74 & 197,49 & 449,17 & 450,45 & $1.818,93$ \\
\hline \multicolumn{2}{|c|}{ Perbandingan } & 1,99 & 0,58 & 0,74 & 0,41 & 0,84 \\
\hline
\end{tabular}

Berdasarkan tabel diatas terlihat bahwa, faktor koreksi layan basah untuk kayu kelapa terbesar terjadi pada kuat tarik sedangkan untuk kuat geser mencapai nilai dua karena hubungan kadar air dan kuat geser sebanding. Jika dilihat dari berat jenisnya, peningkatan faktor layan basah terjadi pada kuat tekan sejajar serat sedangkan untuk kekuatan lainnya terjadi penurunan.

Tabel 8. Faktor Koreksi Layan Basah Kayu Kelapa (Sumber : SNI Konstruksi Kayu 2002)

\begin{tabular}{|c|c|c|c|c|c|}
\hline \multirow{2}{*}{ Umur } & \multirow{2}{*}{$\begin{array}{c}\text { Kuat Geser } \\
\left(\mathbf{k g} / \mathrm{cm}^{2}\right)\end{array}$} & \multicolumn{2}{|c|}{ Kuat Tekan $\left(\mathrm{kg} / \mathrm{cm}^{2}\right)$} & \multirow{2}{*}{$\begin{array}{c}\text { Kuat Lentur } \\
\left(\mathrm{kg} / \mathrm{cm}^{2}\right)\end{array}$} & \multirow{2}{*}{$\begin{array}{c}\text { Kuat Tarik } \\
\left(\mathrm{kg} / \mathrm{cm}^{2}\right)\end{array}$} \\
\hline & & Tegak Lurus Serat & Sejajar Serat & & \\
\hline Perbandingan & 0.97 & 0.67 & 0.8 & 0.85 & 1.00 \\
\hline
\end{tabular}


Jika dibandingkan dengan faktor koreksi pada SNI konstruksi kayu 2002 lampiran B, pasal B.2.1, tabel B.1 seperti pada tabel diatas, faktor koreksi layan basah kayu kelapa lebih rendah. Hal ini disebabkan oleh pori-pori kayu kelapa yang besar menyebabkan peresapan air cepat terjadi, menyebabkan daya ikat antara serat kayu lemah sehingga terjadi kehilangan kekuatan yang besar.

\section{KESIMPULAN}

Berdasarkan hasil analisis dan pengujian yang telah dilakukan, diperoleh kesimpulan sebagai berikut :

1. Peningkatan kadar air kayu kelapa berbanding terbalik secara eksponensial dengan kuat tekan dan kuat tariknya, namun berbanding lurus secara kuadrat dengan kuat gesernya.

2. Terjadi pertambahan kekuatan yang besar pada kayu kelapa dari kadar air $20 \%$ menuju $0 \%$ kecuali untuk kekuatan gesernya.

3. Berdasarkan berat jenis rata-rata yang diperoleh sebesar $0.83 \mathrm{grm} / \mathrm{cm} 3$, maka kayu kelapa berumur 70 tahun termasuk kategori kayu kelas kuat II dan kayu kelapa berumur 20 tahun dengan berat jenis rata-rata $0.58 \mathrm{grm} / \mathrm{cm} 3$ termasuk kategori kayu kelas kuat III dengan nilai kuat lentur yang lebih kecil.

4. Perbedaan kekuatan kayu kelapa pada kondisi kadar air $20 \%$ untuk umur 20 tahun dan 70 tahun adalah $68,74 \%$ pada kuat tekan tegak lurus serat, $56.6 \%$ pada kuat tekan sejajar serat, $10.37 \%$ pada kuat tarik sejajar serat, $32.11 \%$ pada kuat geser dan $13.42 \%$ pada kuat lentur. Perbedaan kekuatan terbesar terjadi pada kekuatan tekan.

5. Faktor koreksi layan basah kayu kelapa lebih rendah dibandingkan faktor koreksi layan basah berdasarkan SNI konstruksi kayu 2002.

\section{DAFTAR PUSTAKA}

Anonim, (1961), Peraturan Konstruksi Kayu Indonesia 1961, Direktorat Penyelidikan Masalah Bangunan, Bandung.

Awaludin, dkk., (2005), Konstruksi Kayu, Jurusan Teknik Sipil Universitas Gadjah Mada, Yogyakarta.

Standar Nasional Indonesia, (2002), Tata Cara Perencanaan Konstruksi Kayu Indonesia, Badan Standarisasi Nasional, Jakarta.

Dumanauw, J.F., (1984), Mengenal Kayu, Pendidikan Industri Kayu (PIKA), Semarang.

Dwianto, W., (2008), Tinjauan Hasil Penelitian Faktor-faktor Alam yang Mempengaruhi Sifat Fisik dan Mekanik Kayu Indonesia, J. Tropical Wood Science and Technology, No.2, Vol. 6.

Haygreen, J.G., Bowyer, J.L., (1996), Hasil Hutan dan Ilmu Ukur Kayu, Universitas Gadjah Mada, Yogyakarta.

Iskandar M.D., Revandy, (2005), Kekuatan Kayu, e-USU Repository.

Isyuanto, S., (2002), Kajian Sifat Mekanik Kayu Kelapa Sebagai Kayu Alternatif di Bidang Konstruksi, Skripsi, FT UJB, Yogyakarta.

Kasmujo, (2001), Identifikasi Kayu dan Sifat-sifat Kayu, Fakultas Kehutanan Universitas Gadjah Mada Yogyakarta.

Sektianto, W., (2001), Tinjauan Sifat Mekanika Kayu Pohon Kelapa Terhadap Rendaman Gamping Dan Daun Jati. Skripsi, FT UJB, Yogyakarta.

Setyamidjaja, (1995), Jenis Kayu Sebagai Bahan Baku Industri Kayu, Skripsi, Fakultas Kehutanan Universitas Gadjah Mada, Yogyakarta. 